\title{
Common solvents for making extraction of allergenic proteins from plants' pollens for prick tests and related factors: a technical review
}

Hassan Mansouritorghabeh ${ }^{1}$, Farahzad Jabbari-Azad ${ }^{2}$, Abdolreza Varasteh $^{3}$, Mojtaba Sankian ${ }^{4}$, Reza FaridHosseini $^{5}$

${ }^{1}$ Ph.D. Student, Allergy Research Center, Mashhad University of Medical Sciences, Mashhad, Iran

${ }^{2}$ M.D., Associate Professor of Allergy and Clinical Immunology, Allergy Research Center, Mashhad University of Medical Sciences, Mashhad, Iran

${ }^{3}$ Ph.D., Professor of Medical School, Allergy Research Center, Mashhad University of Medical Sciences, Mashhad, Iran

${ }^{4}$ Ph.D., Associate Professor of Immunology, Immunology Research Center, Bouali Research Center, Mashhad University of Medical Sciences, Mashhad, Iran

${ }^{5}$ M.D., Professor of Allergy and Clinical Immunology, Allergy Research Center, Mashhad University of Medical Sciences, Mashhad, Iran

Type of article: Review

\begin{abstract}
Collecting information on influencing factors in developing consistent and high-quality extracts results in accurate diagnosis and effective treatment of type I allergy (IgE mediated). Furthermore, considering that a large number of allergens are currently in practice, any attempt to develop a more effective procedure for preparing extract may be useful. Nowadays, different saline solvents, temperature, incubation time, and PH are being incorporated for preparing allergen extracts. The objective of the current study was to clear and address the commonest of solvent buffers and allied conditions for making extracts of pollens of grasses, trees, and weeds. The literature review was done in Jan 2016 on PubMed and Google Scholar medical search engines without any time limitation. After reading abstracts of 87 articles, finally 37 relevant papers were selected and their full texts were retrieved. In conclusion, 24 full-text papers were recognized appropriate and chosen. The extracted information for papers has been described fully in the text. On the basis of these data, PBS buffer with PH 7.4, temperature of $4{ }^{\circ} \mathrm{C}$ and with overnight incubation time, may be the optimized condition in order to have a proper extract for carrying out skin prick tests.

Keywords: Pollens, Plant Proteins, Skin Test, Allergens, Solvents
\end{abstract}

\section{Introduction}

An allergy is an unwanted response of the immune system of the body after exposure to an allergenic material that has entered to the body. Although the manifestation of allergies are not presented in everyone, according to a World Health Organization (WHO) report, sensitization rates of allergies are about $40-50 \%$ among school children globally (1). Prediction risk of allergenic properties of a protein is one of the main challenges in molecular allergies (2). Indeed, the immunogenicity of an allergenic protein reflects its potency to develop the IgE antibody in the human body system $(3,4)$. Some structural characteristics of proteins such as solubility, size, stability, and the compactness of proteins may be relevant to allergenicity power (2). Besides these, the level and route of exposure are important factors in immunogenicity (5). The solubility of an allergen in large amounts upon hydrated condition correlates with its allergenic properties (6). To date, more than 8,000 various allergens have been identified (7). Among them, more than 200 air-borne pollens have been recognized as responsible for respiratory allergies ranging from grasses, trees, and weeds respectively (8-10). The speed of release of allergens in extracts are contributed to some factors

\section{Corresponding author:}

Associate Professor Dr. Farahzad Jabbari-Azad, Allergy Research Center, Ghaem Hospital, School of Medicine, Mashhad University of Medical Sciences, Mashhad, Iran. Zip Code: 91766-99199.

Tel: +98(513)8012770, Fax: +98(513)8428014, Email: Jabbarif@mums.ac.ir

Received: August 07, 2016, Accepted: December 12, 2016, Published: May 2017

iThenticate screening: October 07, 2016, English editing: March 14, 2017, Quality control: April 02, 2017

(C) 2017 The Authors. This is an open access article under the terms of the Creative Commons Attribution-NonCommercialNoDerivs License, which permits use and distribution in any medium, provided the original work is properly cited, the use is non-commercial and no modifications or adaptations are made. 
including location of allergenic proteins in pollens, isoelectric points, solubility, or amino acid composition (11). Also, allergic proteins are located in various parts of pollens including the different layers of the pollen wall (exine, intine, or inner layer) and rough endoplasmic reticulum $(11,12)$. During pollen's, development, allergenic proteins can be followed through transmission electron microscopy immunocytochemical localization technique $(13,14)$. An allergenic protein needs rapid elution or solubility as a prerequisite to behave as a major allergen. This also determines which allergenic protein derives in contact with nasal mucosa (15). The comparison of the two realities that some allergenic proteins are released rapidly, and the point that rhinitis symptoms aggravate within 30 seconds after exposure, results in the postulation that freedom of allergens under natural conditions is also rapid (6). A skin prick test is the common and recommended method for detection of allergies to pollens, foods, dust, pet dander or dust mites worldwide. Furthermore, optimal management of allergies requires accurate diagnosis of the cause of the allergy that is mediated with the skin prick test. Various extract solutions from sources of pollens, foods, dust, pet dander or dust mites are manufactured with various buffer solvents by many companies and are on the market. The quality of allergen extracts that are used for skin prick tests (SPT) has attracted many scientists' views in recent decades. It has been shown that many factors can influence the content of the extract and its quality (16). Owing to more information on influencing factors in developing consistent and high-quality extracts will result in accurate diagnosis and effective treatment of type I allergy $(17,18)$ and moreover regarding a large number of allergens currently used, any attempt in achieving a more effective procedure in preparing extract may be helpful (19). Although reviewing the literature shows that there are different saline solvents, temperature, and $\mathrm{PH}$ that has been recruited for preparing allergen extracts, one relevant but poorly understood feature of preparing an extract is the most ideal type of solvent buffer, temperature, and PH that have been applied. The objectives of the current study were to clear the details of biochemical characterizations of solvent buffers and allied conditions for making extracts of pollens of grasses, trees, and weeds. Hence, a review of the literature on pollens' extracts has been done to address commonly used solvent and relevant biochemical factors.

\section{Strategy of literature review}

The literature assessment was done in Jan 2016 on PubMed and Google Scholar medical search engines without any time limitation, but with language limitation of English. The implemented keywords included: "pollen extract, prick test, solvent, allergenic proteins". Subsequently, after reading 144 titles and abstracts of 87 articles, finally, 37 relevant papers were selected and their full texts were retrieved. In doing so, 24 full-text papers were chosen and recruited in the current review (Figure 1). The inclusion criteria were any published English paper on pollen extracts of plants. The exclusion criteria included any papers on extracts of fungi, food allergens, mites, and animals' allergens.

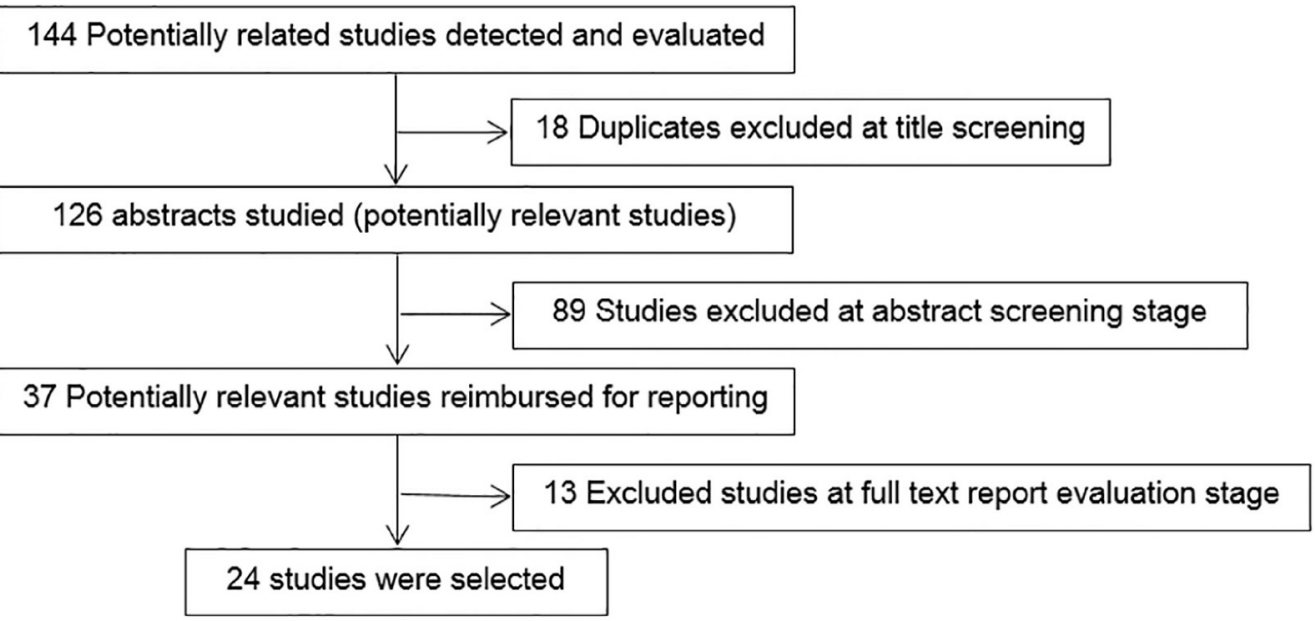

Figure 1. The inclusion and exclusion flow diagram of studied contributions

\section{Results}

The reported extraction procedures which have been used for preparation of various pollens' extracts comprised an extract of Birch (genus Betula) (5 reports), Timothy (Phleum pratense) (4 reports), Mesquite (Prosopis Juliflora) (4 reports), Ash (Fraxinus excelsior) (3 reports), Cedar (Cupressus sempervirens) and Olive (Olea europaea) (2 reports). 
http://www.ephysician.ir

Table 1. The list of reported surveys on used solvents for preparation pollens' extracts before Jan 2016.

\begin{tabular}{|c|c|c|c|c|c|}
\hline $\begin{array}{l}\text { Ref. } \\
\text { no. }\end{array}$ & Type of pollen & Type of used solvents & $\begin{array}{l}\text { Extraction } \\
\text { time (min or } \\
\text { h) }\end{array}$ & $\begin{array}{l}\text { Tem } \\
\left({ }^{\circ} \mathrm{C}\right)\end{array}$ & $\mathrm{PH}$ \\
\hline 20 & Timothy & $\begin{array}{l}0.073 \mathrm{M} \text { Tris, } 0.024 \mathrm{M} \text { barbital, } 0.006 \mathrm{M} \text { calcium } \\
\text { lactate and } 0.003 \mathrm{M} \text { sodium azide }\end{array}$ & $30 \mathrm{~m}$ & 25 & 8.6 \\
\hline 12 & Olive (Olea europaea) & $\begin{array}{l}(50 \mathrm{mM} \text { Tris-HCl, } 300 \mathrm{mM} \mathrm{NaCl}, 1 \mathrm{mM} \text { EDTA, } 1 \\
\text { mM EGTA, } 2 \% \text { Triton X-100, } 5 \mathrm{mM} \text { ascorbic acid, } \\
100 \mathrm{mM} \text { DTT, } 2 \mathrm{mM} \text { PMSF), }\end{array}$ & $\mathrm{N}$ & $\mathrm{N}$ & 7.5 \\
\hline 6 & $\begin{array}{l}\text { Birch (Betula verrucosa), } \\
\text { Timothy (Phleum pretense) }\end{array}$ & $\begin{array}{l}10 \mathrm{mM} \text { potassium phosphate buffer with protease } \\
\text { inhibitors, PHEM-Tx buffer with protease inhibitors }\end{array}$ & $2 \mathrm{~h}$ & 4 & 7 \\
\hline 21 & $\begin{array}{l}\text { Acacia farnesiana (Vachellia } \\
\text { farnesiana) }\end{array}$ & $(\mathrm{PBS}) 0.01 \mathrm{M}$ & $18 \mathrm{~h}$ & 4 & 7.4 \\
\hline 22 & mesquite (Prosopis juliflora) & $\begin{array}{l}\text { Ammonium bicarbonate buffer (50mM NH4HCO3, } \\
1 \mathrm{mM}, \text { PMSF and } 2 \mathrm{mM} \text { EDTA) }\end{array}$ & $4 \mathrm{~h}$ & 4 & 8 \\
\hline 23 & $\begin{array}{l}\text { A. retroflexus (redroot } \\
\text { pigweed) }\end{array}$ & PBS, $0.15 \mathrm{M}$ & Overnight & 4 & 7.4 \\
\hline 24 & Prosopis juliflora (mesquite) & PBS, $0.01 \mathrm{M}$ & $18 \mathrm{~h}$ & 4 & 7.4 \\
\hline 25 & $\begin{array}{l}\text { Japanese cedar (cryptomeria } \\
\text { japonica) }\end{array}$ & Glycerin 50, $\mathrm{NaCl} 5 \%$ & $24 \mathrm{~h}$ & 5 & $\mathrm{~N}$ \\
\hline 26 & White birch (Betula verrucosa) & $\begin{array}{l}0.125 \mathrm{M} \text { ammonium hydrogen carbonate, } 0.015 \mathrm{M} \\
\text { sodium azide, 20mM EDTA, 5mM EACA, } 1 \mathrm{mM} \\
\text { phenylmethylsulfonyl fluoride }\end{array}$ & $20 \mathrm{~h}$ & 4 & 7.1 \\
\hline 27 & Betula verrucosa (white birch) & $0.125 \mathrm{M}$ ammonium hydrogen carbonate & $20 \mathrm{~h}$ & 4 & 7.1 \\
\hline 28 & Timothy (Phleum pratense) & $0.05 \mathrm{M}$ ammonium bicarbonate & $20 \mathrm{~h}$ & 4 & $\mathrm{~N}$ \\
\hline 29 & Chenopodiaceae (Salsola Kali) & (PBS) $0.01 \mathrm{M}$ & $18 \mathrm{~h}$ & 4 & 7.4 \\
\hline 24 & Mesquite (Prosopis juliflora) & (PBS) $0.01 \mathrm{M}$ & $18 \mathrm{~h}$ & 4 & 7.4 \\
\hline 31 & Cypress (six genera) & Ammonium bicarbonate & $24 \mathrm{~h}$ & 4 & $\mathrm{~N}$ \\
\hline 30 & Ash (Fraxinus excelsior) & Ammonium bicarbonate $4-\mathrm{g} / 1$ & $24 \mathrm{~h}$ & 4 & $\mathrm{~N}$ \\
\hline 22 & mesquite (Prosopis juliflora) & Ammonium bicarbonate buffer & $4 \mathrm{~h}$ & 4 & 8 \\
\hline 39 & Hazel pollen & $\begin{array}{l}0.125 \mathrm{M} \text { Ammonium hydrogen carbonate, } 0.015 \mathrm{M} \\
\text { sodium azide, 20mM EDTA, 5mM EACA, } 1 \mathrm{mM} \\
\text { phenylmethylsulfonyl fluoride (PMSF) }\end{array}$ & $20 \mathrm{~h}$ & 4 & 7.1 \\
\hline 38 & $\begin{array}{l}\text { Cedar (Cryptomeria } \\
\text { japonica) }\end{array}$ & $\mathrm{NaCl}(5 \%)$ & $24 \mathrm{~h}$ & 5 & $\mathrm{~N}$ \\
\hline 32 & $\begin{array}{l}\text { Timothy, olive (O. euro-paea), } \\
\text { Ash, (F. excelsior), birch } \\
\text { (Betula verrucosa) }\end{array}$ & PBS & Overnight & 4 & 7.4 \\
\hline 33 & Ash (Fraxinus excelsior) & PBS & Overnight & 4 & 7.4 \\
\hline 34 & Amaranthus palmeri & $50 \mathrm{mM}$ carbonate buffer & $16 \mathrm{~h}$ & 4 & 8 \\
\hline 35 & 4 species of Brassica & bmmonium bicarbonate buffer & Overnight & 4 & 7.4 \\
\hline 36 & maize pollen & PBS & Overnight & $\mathrm{N}$ & 7.2 \\
\hline 37 & $\begin{array}{l}\text { Shasta Daisy (Chrysanthemum } \\
\text { maximum) }\end{array}$ & PBS & $18 \mathrm{~h}$ & 4 & 7.4 \\
\hline
\end{tabular}

$\mathrm{PH}$; potential hydrogen, $\mathrm{N}$; not cited in full text, Tem; temperature, h; hours, mM; mili-molar, g/l; gram per liter, ${ }^{\circ} \mathrm{C}$; degree of Celsius.

Through 24 studied full-text papers (Table 1) $(6,12,20-39)$, the following approaches were used:

1) Solvent buffers: Different buffers have been used to prepare pollen extracts. The commonest used buffers included phosphate buffer saline (PBS) 9/24 (37.5\%) and ammonium bicarbonate buffer 8/24 (33.3\%).

2) Temperatures: The commonest used temperature to prepare pollen extracts were $4{ }^{\circ} \mathrm{C}$ with 19 reports $(86 \%), 5{ }^{\circ} \mathrm{C}$ - two reports $(9.1 \%)$ and $25{ }^{\circ} \mathrm{C}$ - one paper $(4.5 \%)$. The minimum and maximum used temperatures were 4 and $25^{\circ} \mathrm{C}$ with a mean of $5.04 \pm 4.46$ and median 4 .

3) PH: Among the 24 surveys under study, 5 papers did not report using $\mathrm{PH}, 9$ of them had used physiologic $\mathrm{PH}$ of $7.4(47.4 \%)$ and three of them had used PH of 8 and $7.1(5.8 \%)$. The minimum and maximum used PH were 7 and 8.6 respectively. The mean of PH was $7.48 \pm 0.39 \mathrm{SD}$ and with median 7.4.

Extraction time: The time for preparing pollen extracts varied from $30 \mathrm{~min}$ to overnight incubation time. The commonest used incubation times were overnight with 5 cases $(20.8 \%)$ and 18 hours with 5 cases $(20.8 \%)$. The lowest reported time used for extraction of pollen proteins was $30 \mathrm{~min}$. 


\section{Discussion and Conclusions}

Among various studied influencing parameters, the used buffer solvent had the widest spectrum of varieties (40). Even there, were varieties among the concentration of specific salts in a certain solvent buffer (41). It seems researchers select their solvent buffer according to their personal experiences. In order to obtain standard extracts, one approach would be the usage of a standard protocol to make the extract. However, this could not be implemented due to a large number of protocols having been used to prepare pollen grain extracts. In biological studies, PBS is used commonly as a buffer solution. PBS is a water-based salt solution, non-toxic, with ion concentration and osmolality similar to the human body. Hence, it can be used as a premium buffer due to similarity with body fluids. This review showed that the most used extraction buffer has been PBS. It seems that relevant factors such as its simple ingredients, non-toxicity, and having similar osmolality with the body has been influencing to select it as an optimum buffer to make an extract. The temperature in which extraction procedure is done, is an effective factor in releasing allergenic proteins from pollens' grains. It has been documented that harsh extraction procedure (boiling pollen grain in the buffer) can discharge non-allergenic proteins, for instance, heat shock protein 70 (41). Incubation in $37^{\circ} \mathrm{C}$ can result in releasing of unidentified proteins too. Moreover, it has been shown that thermals induce structural changes in processing proteins (42). Hence, extraction procedure would be done at low temperatures. Accordingly, $79.1 \%$ of the reported survey had carried out extraction procedure in $4{ }^{\circ} \mathrm{C}$ and only 3 reports had carried out extraction in $35{ }^{\circ} \mathrm{C}$ and $5{ }^{\circ} \mathrm{C}$. On the other hand, the temperature and water content of airway mucosa is dynamic between plasma and inspired air, and would be expected to be lower than the core temperature of the body system (43-45). To mimic normal conditions during pollen exposure into the human mucosa and similar releasing allergenic proteins, selection of temperature lower than $37^{\circ} \mathrm{C}$ seems a logical option. This reality has been implemented in selection of temperature for extraction, accounting for as much as $79.1 \%$ of available literature that have shown to have used $4{ }^{\circ} \mathrm{C}$. It has been demonstrated that fluctuation of PH of a solution can change side chains of the protein and its final shape, and also, small changes in the shape of a protein can lead to a large effect on the manner the protein behaves $(46,47)$. Proteins may alter their shape in response to changes in parameters such as PH, the polarity of the solvent, temperature and concentration of ions and molecules that can attach to it (48). Going through available literature, confirmed that most reported used PH was physiologic PH of 7.4. This will provide a similar condition in liberating allergenic pollens both on human mucosa and what happens in extraction procedure. Needless to say, with increasing time of extraction, more proteins will have the opportunity to release both in number of proteins and in their concentration into solution. Both overnight incubation and 18 hour incubation times have been used in most procedures and it looks as though there is no remarkable difference between them due to an overnight incubation time taking time as much as $18 \mathrm{~h}$. In short incubation time, there may be a possibility to miss some proteins that need more time for releasing such as the profilin family ( a cytoskeletal protein) (48), so, only one paper has reported usage of this timeframe for developing extract. It would appear prudent, on the basis of these data to select extraction buffer of PBS with PH 7.4 and temperature of $4{ }^{\circ} \mathrm{C}$ with overnight incubation time not to miss any proteins from pollen grains, and in order to have a proper extract for carrying out a skin prick test.

\section{Acknowledgments:}

This work was granted by vice chancellor of research in Mashhad University of Medical Sciences (grant no. 931396). This work was part of a $\mathrm{PhD}$ thesis of the first author.

\section{Conflict of Interest:}

There is no conflict of interest to be declared.

\section{Authors' contributions:}

All authors contributed to this project and article equally. All authors read and approved the final manuscript.

\section{References:}

1) World Health Organization. White Book on Allergy 2011-2012 Executive Summary. By Prof. Ruby Pawankar, MD, PhD, Prof. Giorgio Walkter Canonica, MD, Prof. Stephen T. Holgate, BSc, MD, DSc, FMed Sci and Prof. Richard F. Lockey, MD.

2) Aalberse RC. Structural biology of allergens. Journal of Allergy and Clinical Immunology. 2000;106(2):228-38. DOI: 10.1067/mai.2000.108434, PMid: 10932064

3) Lehrer SB, Horner WE, Reese G, Taylor S. Why are some proteins allergenic? Implications for biotechnology. Critical Reviews in Food Science \& Nutrition. 1996;36(6):553-64. DOI: 10.1080/10408399609527739, PMid: 8841731 
4) Kimber I, Kerkvliet NI, Taylor SL, Astwood JD, Sarlo K, Dearman RJ. Toxicology of protein allergenicity: prediction and characterization. Toxicological Sciences. 1999;48(2):157-62. DOI: 10.1093/toxsci/48.2.157, PMid: 10353306

5) Dearman RJ, Kimber I. Determination of protein allergenicity: studies in mice. Toxicology letters. 2001;120(1):181-6. DOI: 10.1016/S0378-4274(01)00276-4

6) Vrtala S, Grote M, Duchene M, VanRee R, Kraft D, Scheiner O, et al. Properties of tree and grass pollen allergens: reinvestigation of the linkage between solubility and allergenicity. Int Arch Allergy Immunol. 1993;102(2):160-9. DOI: 10.1159/000236567, PMid: 8400895

7) Kofler S, Ackaert C, Samonig M, Asam C, Briza P, Horejs-Hoeck J, et al. Stabilization of the dimeric birch pollen allergen Bet v 1 impacts its immunological properties. J Biol Chem. 2014;289(1):540-51. DOI: 10.1074/jbc.M1 13.518795, PMid: 24253036, PMCid: PMC3879576

8) Dhyani A, Arora N, Gaur SN, Jain VK, Sridhara S, Singh BP. Analysis of IgE binding proteins of mesquite (Prosopis juliflora) pollen and cross-reactivity with predominant tree pollens. Immunobiology. 2006;211(9):733-40. DOI: 10.1016/j.imbio.2006.03.003, PMid: 17015148

9) Singh AB, Kumar P. Aeroallergens in clinical practice of allergy in India. An overview. Annals of agricultural and environmental medicine: AAEM. 2003(10):131-6. PMid: 14677902

10) Singh AB, Shahi S. Aeroallergens in clinical practice of allergy in India-ARIA Asia Pacific Workshop report. Asian Pac J Allergy Immunol. 2008;26(4):245-56. PMid: 19317344

11) Carnes J, Fernandez-Caldas E, Boluda L, Casanovas M, Sastre J, Lluch Bernal M, et al. Rapid release of Ole e 1 from olive pollen using different solvents. Allergy. 2002;57(9):798-804. DOI: 10.1034/j.13989995.2002.23568.x, PMid: 12169175

12) de Dios Alché J, Castro AJ, Olmedilla A, Fernandez MdC, Rodríguez R, Villalba M, et al. The major olive pollen allergen (Ole e I) shows both gametophytic and sporophytic expression during anther development and its synthesis and storage takes place in the RER. Journal of cell science. 1999;112(15):2501-9. PMid:10393806

13) Martín-Orozco E, Cárdaba B, Del Pozo V, De Andres B, Villalba M, Gallardo S, et al. Ole e I: epitope mapping, cross-reactivity with other Oleaceae pollens and ultrastructural localization. Int Arch Allergy Immunol. 1994;104(2):160-70. DOI: 10.1159/000236725, PMid:7515294

14) Rodríguez-García MI, Fernández MC, Alché J. Immunocytochemical localization of allergenic protein (Ole e I) in the endoplasmic reticulum of the developing pollen grain of olive (Olea europaea L.). Planta. 1995;196(3):558-63. DOI: 10.1007/BF00203656

15) Gupta N, Sriramarao P, Kori R, Rao PS. Immunochemical characterization of rapid and slowly released allergens from the pollen of Parthenium hysterophorus. Int Arch Allergy Immunol. 1995;107(4):557-65. DOI: 10.1159/000237099, PMid:7620370

16) Nelson HS, Iklé D, Buchmeier A. Studies of allergen extract stability: the effects of dilution and mixing. Journal of allergy and clinical immunology. 1996;98(2):382-8. DOI: 10.1016/S0091-6749(96)70162-8

17) Ali-Sadeghi H, Khodadadi A, Amini A, Assarehzadegan M-A, Sepahi N, Zarinhadideh F. Pro j 2 is mesquite profilin: molecular characteristics and specific IgE binding activity. Asian Pacific Journal of Allergy and Immunology. 2014;33(2)

18) Cox L. Standardized allergen extracts: past, present and future. Expert Rev Clin Immunol. 2005;1(4):57988. DOI: 10.1586/1744666X.1.4.579, PMid: 20477599

19) Baer H. Standardization of allergenic extracts. Clinical Immunology Newsletter. 1981;2(12):94-6. DOI: 10.1016/S0197-1859(81)80039-8

20) Løwenstein H. Isolation and partial characterization of three allergens of timothy pollen. Allergy. 1978;33(1):30-41. DOI: 10.1111/j.1398-9995.1978.tb01504.x, PMid:646072

21) Shamsbiranvand M-H, Khodadadi A, Assarehzadegan M-A, Borsi SH, Amini A. Immunochemical characterization of acacia pollen allergens and evaluation of cross-reactivity pattern with the common allergenic pollens. Journal of allergy. 2014;2014.

22) Dhyani A, Arora N, Gaur SN, Jain VK, Sridhara S, Singh BP. Analysis of IgE binding proteins of mesquite (Prosopis juliflora) pollen and cross-reactivity with predominant tree pollens. Immunobiology. 2006;211(9):733-40. DOI: 10.1016/j.imbio.2006.03.003, PMid: 17015148

23) Tehrani M, Sankian M, Assarehzadegan MA, Falak R, Noorbakhsh R, Moghadam M, et al. Identification of a new allergen from Amaranthus retroflexus pollen, Ama r 2. Allergology International. 2011;60(3):30916. DOI: 10.2332/allergolint.10-OA-0279, PMid:21430432

24) Assarehzadegan M-A, Khodadadi A, Amini A, Shakurnia A-H, Marashi SS, Ali-Sadeghi H, et al. Immunochemical Characterization of Prosopis Juliflora Pollen Allergens and Evaluation of Cross- 
Reactivity Pattern with the Most Allergenic Pollens in Tropical Areas. Iranian Journal of Allergy, Asthma and Immunology. 2014;14(1):74-82.

25) Yasueda $H$, Okuda $M$, Yoshida $H$, Ito $K$, Baba $M$, Iikura $Y$, et al. A basic policy for allergen standardization in our country and standardization of Japanese cedar (Cryptomeria japonica) pollen extracts. Allergology International. 1997;46(2):135-40. DOI: 10.2332/allergolint.46.135

26) Jarolim E, Rumpold H, Endler A, Ebner H, Breitenbach M, Scheiner O, et al. IgE and IgG antibodies of patients with allergy to birch pollen as tools to define the allergen profile of Betula verrucosa*. Allergy. 1989;44(6):385-95. DOI: 10.1111/j.1398-9995.1989.tb04169.x, PMid:2802112

27) Jarolim E, Rumpold H, Endler A, Schlerka G, Ebner H, Scheiner O, et al. Specificities of IgE and IgG antibodies in patients with birch pollen allergy. Int Arch Allergy Immunol. 1989;88(1-2):180-2. DOI: $10.1159 / 000234778$

28) Anderson MC, Baer H. Antigenic and allergenic changes during storage of a pollen extract. Journal of Allergy and Clinical Immunology. 1982;69(1):3-10. DOI: 10.1016/0091-6749(82)90080-X

29) Assarehzadegan MA, Sankian M, Jabbari F, Noorbakhsh R, Varasteh A. Allergy to Salsola Kali in a Salsola incanescens-rich area: role of extensive cross allergenicity. Allergology International. 2009;58(2):261-6. DOI: 10.2332/allergolint.08-OA-0041, PMid:19307776

30) Hrabina M, Purohit A, Oster J-P, Papanikolaou I, Jain K, Pascal P, et al. Standardization of an ash (Fraxinus excelsior) pollen allergen extract. Int Arch Allergy Immunol. 2007;142(1):11-8. DOI: 10.1159/000095994, PMid:17016054

31) Hrabina M, Dumur JP, Sicard H, Viatte A, Andre C. Diagnosis of cypress pollen allergy: in vivo and in vitro standardization of a Juniperus ashei pollen extract. Allergy. 2003;58(8):808-13. DOI: $10.1034 / \mathrm{j} .1398$ 9995.2003.00247.x, PMid:12859563

32) Palomares O, Swoboda I, Villalba M, Balic N, Spitzauer S, Rodriguez R, et al. The major allergen of olive pollen Ole e 1 is a diagnostic marker for sensitization to Oleaceae. Int Arch Allergy Immunol. 2006;141(2):110-8. DOI: 10.1159/000094713, PMid:16864978

33) Hemmer W, Focke M, Wantke F, Gotz M, Jarisch R, Jager S, et al. Ash (Fraxinus excelsior)-pollen allergy in central Europe: specific role of pollen panallergens and the major allergen of ash pollen, Fra e 1. Allergy. 2000;55(10):923-30. DOI: 10.1034/j.1398-9995.2000.00671.x, PMid:11030372

34) Landa-Pineda CM, Arroyo-Becerra A, Rosas-Alvarado A, Teran LM, Garcia-Cruz ML, Marchat LA, et al. Major allergen from Amaranthus palmeri pollen is a profilin: Isolation, partial characterisation and $\operatorname{IgE}$ recognition. Allergol Immunopathol. 2015;24(15):00098-1.

35) Singh A, Shahi S, Katiyar RK, Gaur S, Jain V. Hypersensitivity to pollen of four different species of Brassica: a clinico-immunologic evaluation in patients of respiratory allergy in India. Asia Pac Allergy. 2014;4(4):197-205. DOI: 10.5415/apallergy.2014.4.4.197, PMid: 25379479 PMCid: PMC4215438

36) Taala L, Majd A, Nourizadeh M, Pourpak Z. Identifying the allergenicity of maize pollen in Iran. Arch Iran Med. 2014;17(7):490-4. PMid: 24979562

37) Sharif Shoushtari M, Majd A, Pourpak Z, Shahali Y, Moin M, Eslami MB. Differential allergenicity of mature and immature pollen grains in Shasta daisy (Chrysanthemum maximum Ramond). Iranian journal of allergy, asthma, and immunology. 2013;12(2):99-106. PMid: 23754347

38) Yasueda H, Yui Y, Shimizu T, Shida T. Isolation and partial characterization of the major allergen from Japanese cedar (Cryptomeria japonica) pollen. Journal of Allergy and Clinical Immunology. 1983;71(1):77-86. DOI: 10.1016/0091-6749(83)90550-X

39) Hirschwehr R, Valenta R, Ebner C, Ferreira F, Sperr WR, Valent P, et al. Identification of common allergenic structures in hazel pollen and hazelnuts: a possible explanation for sensitivity to hazelnuts in patients allergic to tree pollen. J Allergy Clin Immunol. 1992;90(6 Pt 1):927-36. DOI: 10.1016/00916749(92)90465-E

40) Ciocca DR, Oesterreich S, Chamness GC, MCGuire WL, Fuqua SA. Biological and clinical implications of heat shock protein 27000 (Hsp27): a review. Journal of the National Cancer Institute. 1993;85(19):1558-70. DOI: $10.1093 /$ jnci/85.19.1558, PMid: 8411230

41) Stănciuc N, Aprodu I, Râpeanu G, van der Plancken I, Bahrim G, Hendrickx M. Analysis of the thermally induced structural changes of bovine lactoferrin. Journal of agricultural and food chemistry. 2013;61(9):2234-43. DOI: 10.1021/jf305178s, PMid: 23410159

42) Williams R, Rankin N, Smith T, Galler D, Seakins P. Relationship between the humidity and temperature of inspired gas and the function of the airway mucosa. Critical care medicine. 1996;24(11):1920-9. DOI: 10.1097/00003246-199611000-00025, PMid: 8917046 
43) McFadden E, Pichurko B, Bowman HF, Ingenito E, Burns S, Dowling N, et al. Thermal mapping of the airways in humans. Journal of Applied Physiology. 1985;58(2):564-70. PMid: 3980358

44) Primiano F, Saidel G, Montague F, Kruse K, Green C, Horowitz J. Water vapour and temperature dynamics in the upper airways of normal and CF subjects. European Respiratory Journal. 1988;1(5):40714, PMid: 3169211

45) Dumetz AC, Chockla AM, Kaler EW, Lenhoff AM. Effects of $\mathrm{pH}$ on protein-protein interactions and implications for protein phase behavior. Biochimica et Biophysica Acta (BBA)-Proteins and Proteomics. 2008;1784(4):600-10. DOI: 10.1016/j.bbapap.2007.12.016, PMid:18258214

46) Fang B, Zhang M, Jiang L, Jing H, Ren FZ. Influence of $\mathrm{pH}$ on the structure and oleic acid binding ability of bovine $\alpha$-lactalbumin. The protein journal. 2012;31(7):564-72. DOI: 10.1007/s10930-012-9434-5, PMid: 22814573

47) Di Russo NV, Estrin DA, Martí MA, Roitberg AE. pH-Dependent Conformational Changes in Proteins and Their Effect on Experimental pK as: The Case of Nitrophorin 4. 2012.

48) Valenta R, Ferreira F, Grote M, Swoboda I, Vrtala S, Duchêne M, et al. Identification of profilin as an actin-binding protein in higher plants. Journal of Biological Chemistry. 1993;268(30):22777-81. PMid: 7693678 